\title{
Dinamika Fatwa dari Klasik ke Kontemporer (Tinjauan Karakteristik Fatwa Ekonomi Syariah Dewan Syariah Nasional Indonesia (DSN-MUI)
}

\author{
Soleh Hasan Wahid \\ IAIN Ponorogo \\ wahid@iainponorogo.ac.id
}

\begin{abstract}
This article discusses the change in the characteristics of fatwas from classical fatwas to contemporary fatwas, especially Islamic economic fatwas in Indonesia when compared to previous ulama fatwas. From the results of this study, the authors conclude that the change in the characteristics of the DSN-MUI fatwa lies in; a) fatwa which has binding legal force based on the Law; b) fatwa is intended specifically for financial institutions and special authorities in the field of sharia economics; c) fatwa is no longer an answer to a question but an active response from DSN-MUI.
\end{abstract}

Keywords: classical fatwa, contemporary fatwa, Islamic economic fatwa

\begin{abstract}
Abstrak
Artikel ini membahas mengenai perubahan karakteristik fatwa dari fatwa klasik ke fatwa kontemporer, khususnya fatwa ekonomi syariah di Indonesia jika dibandingkan dengan fatwa-fatwa ulama terdahulu. Dari hasil penelitian ini, penulis menyimpulkan bahwa perubahan karakteristikfatwa DSN-MUI terletak pada; a) fatwa yang memiliki kekuatan hukum mengikat berdasarkan UndangUndang; b) fatwa ditujukan khusus bagi lembaga keuangan dan kewenangan khusus di bidang ekonomi syariah; c) fatwa tidak lagi merupakan jawaban atas suatu pertanyaan akan tetapi respon aktif dari DSN-MUI.
\end{abstract}

Kata Kunci: fatwa klasik, fatwa kontemporer, fatwa ekonomi syariah

\section{PENDAHULUAN}

Dinamisnya permasalahan di bidang ekonomi syariah yang membutuhkan adanya dasar hukum yang tepat dan disepakati secara nasional maupun internasional. Lembaga Fatwadi Indonesia yakni DSNMUI, Lajnah Bahth al-Masā'il dan Majelis Tarjīh yang tentu memiliki basis masa yang kuat merupakan kiblat hukum bagi masyarakat khususnya di Indonesia dalam menyelesaikan persoalan hukum yang mereka hadapi.Keberadaan lembaga-lembaga tersebut memiliki latar belakang yang berbeda-beda, DSN-MUI merupakan salah satu lembaga yang paling mencolok bila dikaitkan dengan ekonomi syariah.Sampai saat ini jumlah fatwa yang dimiliki oleh lembaga tersebut sampai detik in berjumlah 125 
fatwa di bidang ekonomi syariah. (https://dsnmui.or.id/kategori/fatwa/ di akses 05 Agustus 2019).

Kehadiran fatwa-fatwa ini menjadi aspek organik dari bangunan ekonomi islami yang tengah ditata/dikembangkan, sekaligus merupakan alat ukur bagi kemajuan ekonomi syari'ah di Indonesia. Fatwa ekonomi syari'ah yang telah hadir itu secara teknis menyuguhkan model pengembangan bahkan pembaharuan fiqh muamalah maliyah. (fiqh ekonomi). (https://www.pesantrenvirtual.com/ fatwa-ekonomi-syariahdi-indonesia/ di akses 05 Agustus 2019)

Hal menarik berkaitan dengan produk fatwa masing-masing lembaga tersebut terutama DSN-MUI adalah bahwa karakter fatwa yang dikeluarkan telah mengalami perubahan jika dibandingkan dengan karakter fatwa-fatwa ulama terdahulu. Rumusan-rumusan fatwanya pun juga terlihat berbeda. Fatwa dengan definisi klasik mengalami pengembangan dan penguatan posisi dalam fatwa kontemporer yang melembaga dan kolektif di Indonesia. Baik yang dikeluarkan oleh Komisi Fatwa MUI untuk masalah keagamaan dan kemasyarakatan secara umum, maupun yang dikeluarkan oleh DSN MUI untuk fatwa tentang masalah ekonomi syari'ah khususnya Lembaga Ekonomi Syari'ah. Fatwa yang dikeluarkan oleh Komisi Fatwa MUI menjadi rujukan yang berlaku umum serta mengikat bagi ummat Islam di Indonesia, khususnya secara moral. Sedang fatwa DSN menjadi rujukan yang mengikat bagi lembagalembaga keuangan syari'ah (LKS) yang ada di tanah air, demikian pula mengikat masyarakat yang berinteraksi dengan LKS (https://www.pesantrenvirtual.com/fatwa-ekonomi-syariah-diindonesia/ di akses 05 Agustus 2019). Struktur dan format fatwa sudah memadai dengan rumusan yang simple. Jika dibandingkan dengan format fatwa mufti Mesir misalnya, fatwa DSN MUI lebih komplet muatannya. Namun format fatwa DSN-MUI hanya terbatas memberikan penentuan status hukum masalah yang difatwakan, belum bersifat "ifadah 'ilmiah" yakni memberikan kegunaan pencerahan wawasan keilmuan, sehingga kurang memberikan bekalan kepada kalangan di luar para ulama ekonomi syariah. Karena itu disarankan agar setiap fatwa disertai lampirannya, berupa uraian ilmiyah singkat yang mengantarkan pada kesimpulan-kesimpulan isi fatwa (https://www.pesantrenvirtual.com/fatwa-ekonomi-syariah-diindonesia/ di akses 05 Agustus 2019, 2006).

Oleh karena itu, penilitian ini mencoba mengkaji lebih detail berkaitan dengan perubahan karakter fatwa lembaga-lembaga fatwa di Indonesia khususnya berkaitan dengan fatwa ekonomi syariah. 
Rumusan masalah dari tulisan ini adalah bagaimana perubahan karakterisktik fatwa ekonomi syariah DSN-MUI. Jenis penelitian ini adalah library research (penelitian kepustakaan), yaitu penelitian yang dilaksanakan dengan menggunakan literatur (kepustakaan), baik berupa buku, catatan, maupun laporan hasil penelitian dari penelitian terdahulu. Dengan menggunakan pendekatancontent analisisdan comparative approach.

Artikel ini bermanfaat dalam memahamai karakteristik produkproduk fatwa ekonomi syariah di Indonesia dan memahamipendekatan, metode dan format fatwa dalam produk-produk fatwa lembaga fatwa di Indonesia. Sehingga dapat dijadikan dasar pijakan dalam upaya pengembangan dan pembangunan sistem ekonomi syariah di Indonesia.

\section{Pengertian dan Bentuk Fatwa}

Fatwa menurut bahasa berarti jawaban mengenai suatu kejadian atau peristiwa ( memberikan jawaban yang tegas terhadap segala peristiwa yang terjadi dalam masyarakat) (Yusuf Qardawi, 1990: 5). Menurut Zamakhysri dalam bukunya al-Kasyaf pengertian fatwa adalah suatu jalan yang lempeng atau lurus (Rohadi Abdul Fatah, 2006: 7).

Dalam ilmu Ușul Figh, fatwa berarti pendapat yang dikemukakan seorang mujtahid atau fäqih sebagai jawaban yang diajukan peminta fatwa dalam suatu kasus yang sifatnya tidak mengikat (Abdul Aziz Dahlan, 1996: 326). Fatwa juga dapat diterjemahkan sebagai petuah, nasehat, jawaban atas pertanyaan yang berkaitan dengan hokum (Depdikbud, Kamus Besar Bahasa Indonesia, 1997: 275).

Sedangkan secara terminologi, sebagaimana dikemukakan oleh Zamakhysri fatwa adalah penjelasan hukum syara' tentang suatu masalah atas pertanyaan seseorang atau kelompok. Menurut al-Syäțibi, fatwa dalam arti al-iftä' berarti keterangan-keterangan tentang hukum syara' yang tidak mengikat untuk diikuti (Wahbah Zuhaily, 1990: 98). Menurut kitab Mațalib Üly al-Nuhā fi Syarh Ghayah al-Munțaha, pengertian fatwa adalah menjelaskan hukum syar'i kepada penannya dan tidak mengikat untuk dipilih (Mațalib Ūly al-Nuhā fi Syarḥ Ghayah al-Munțaha: 168). Menurut Yusuf Qardawi, fatwa adalah menerangkan hukum syara' dalam persoalan sebagai jawaban atas pertanyaan yang diajukan oleh peminta fatwa (mustafti) baik secara perorangan maupun kolektif (Yusuf Qardawi, 1990: 203). Menurut Joseph Scaht fatwa didefinisikan sebagai “ formal legal opini" (opini legal formal) (Joseph Schacht, 1965: 74).

Fatwa mempunyai kedudukan penting dalam agama Islam. Fatwa atau ketetapan ulama dipandang menjadi salah satu alternatif yang bisa memecahkan kebekuan dalam perkembangan hukum Islam. Hukum 
Islam yang dalam penetapannya tidak bisa terlepas dari dalil-dalil keagamaan (al-nușuṣ al-syari'iyah) menghadapi persoalan serius ketika berhadapan dengan permasalahan yang semakin berkembang yang tidak tercangkup dalam naṣ-naṣ keagamaan. Naș-naș keagamaan telah berhenti secara kuantitasnya, akan tetapi diametral permasalahan dan kasus semakin berkembang pesat seiring dengan perkembangan zaman (Maslihan Mohammad Ali, 2015: 21-22). Dalam kondisi seperti inilah fatwa menjadi salah satu alternatif jalan keluar mengurai permasalahan dan peristiwa yang muncul.

Sehubungan dengan fatwa, Nasroen Haroen menjelaskan beberapa istilah yang berkaitan dengan proses pemberian fatwa, yakni:

1. Al-Iftā' atau al-Futya, artinya kegiatan menerangkan hukum syara' sebagai jawaban atas pertanyaan yang diajukan.

2. Mustafti, artinya individu atau kelompok yang mengajukan pertanyaan atau meminta fatwa.

3. Mufti, orang yang memberikan jawaban atas pertanyaan tersebut atau orang yang memberikan fatwa.

4. Mustafti fih, masalah, peristiwa, kejadian, kasus, perkara yang ditanyakan status hukumnya (Nasroen Haroen, 2001: 203).

Sehubungan dengan bentuk fatwa ini, dalam kaitan dengan format, fatwa terdiri dari tiga unsur pertanyaan (su'äl,istiftä), pemberi fatwa (mufti), dan jawaban (jawāb). Seseorang (mustaftī) mengajukan suatu pertanyaan kepada seorang mufti, yang kemudian mufti tersebut menyediakan jawabannya. Ketika pertanyaan tersebut disusun atau ditulis pada sehelai kertas, maka kertas tersebut kemudian dikenal sebagai ruq'ah al-istiftā' dan kitāb al-istiftā' (Wael B. Hallaq, From Fatwās to Furu': Growth and Change in Islamic Subtantive Law, (Islamic Law and Society. Vol.1. No.1 (1994: 31)). Menurut Wael B.Hallaq himpunan fatwa dapat diklasifikan menjadi dua bentuk pertama primary fatwā dan secondary fatwā.

Dalam bentuk primernya (primary fatwa), fatwa memiliki ciri-ciri sebagai berikut:

1. Keseluruhan fatwa selalu dimulai dengan kata-kata seperti "Dia ditanya..." dan diakhir diikuti dengan kata "Dia menjawab...". Beberapa ahli hukum Islam, seperti Ibnu Rusyd dalam memberikan fatwa biasa mencantumkan kalimat "saya telah membaca dengan seksama pertanyaan anda dan mempertimbangkannya dengan hati-hati" (tașaffaḥtu su'ālaka wa- 
waqaftu 'alayh) atau kalimat serupa lainya (Wael B. Hallaq, 1994: 32).

2. Hampir keseluruhan fatwa berkisar mengenai permasalah khusus yang dialami seseorang atau beberapa orang. Baik primary fatwā maupun secondary fatwā selalu menampilkan dasar dari realitas yang sedang terjadi dan praktik hukum dalam suatu koleksi fatwa (Wael B. Hallaq, 1994: 33).

3. Fatwa selalu dilengkapi dengan komentar tambahan atau pertanyaan lain yang diajukan mustaftī yang telah dijawab oleh ahli hukum dalam satu ruq'a yang sama (Wael B. Hallaq, 1994: 33).

4. Primary fatwa, sering mencantumkan frasa-frasa yang tidak berkaitan dengan hukum, akan tetapi memilik peran untuk menunjukkan bahwa suatu peristiwa memang terjadi dari realitas aktual. Seperti pertanyaan yang mencantumkan mata uang tertentu atau berat dari sesuatu (contoh., dīnār Nāṣirì, dìnār Șūrì) merupakan contoh dari bentuk ini. Yang lebih penting dalam fatwa adalah pihak-pihak yang terlibat dalam permasalahan hukum yang dimintakan fatwanya. Hal tersebut seringkali disebutkan dalam fatwa, akan tetapi tidak mempengaruhi aturan, alasannya adalah untuk menunjukkan bahwa fatwa memang benar-benar berasal dari realitas. Akan tetapi dalam praktik seringkali nama-nama tersebut dihilangkan dan diganti dengan nama samaran seperti Zayd dan 'Amr (Wael B. Hallaq, 1994: 34).

5. Kebanyakan susunan pertanyaan dalam fatwa bersifat legalistik. Kebiasaan seperti ini terjadi disebabkan para ahli hukum pada waktu itu menolak untuk menjawab pertanyaan kecuali pertanyaan tersebut dirumuskan dan ditulis oleh seorang ahli pembuat draft hukum. Pada masa Utsmāni, Syekh al-Islām enggan untuk menjawab pertanyaan yang disusun oleh pribadi. Dalam pedoman fatwa merekomendasikan bahwa ketika pertanyaan tidak jelas atau terlalu umum, maka muftī harus mewancarai secara detail terhadap penanya, dan kemudian merumuskannya dalam bahasa hukum, kemudian memberikan jawaban atas pertanyaan tersebut (Wael B. Hallaq, 1994: 35).

6. Dalam fatwa yang berhubungan dengan kontrak, mufti selalu melampirkan draft kontrak yang menjadi permasalahan. Hal ini menunjukkan bahwa permasalahan memang benar-benar terjadi dan bukan karangan muftī semata (Wael B. Hallaq, 1994: 35).

7. Sejak fatwa memiliki fungsi sebagai doktrin pendukung dalam kasus yang terjadi diperadilan, para praktisi telah mencatatnya 
dalam catatan peradilan. Fakta ini mengindikasikan bahwa fatwa sejak saat itu telah dirumuskan dalam suatu koleksi tertentu (Wael B. Hallaq, 1994: 35).

8. Beberapa fatwa tampak bersifat hipotesis, berurusan dengan masalah "akademis" atau menyikapi masalah yang murni "teoritis". Meskipun begitu,pada dasarnya permasalahan tetap didasarkan pada relaitas yang sebenarnya terjadi, rumusanrumusan hipotesis tersebut merupakan hasil formulasi atas berbagai masalah yang sesungguhnya terjadi(Wael B. Hallaq, 1994: 36).

9. Kebanyakan fatwa disusun berdasarkan urutan permasalahan yang muncul. Dalam fatwanya, Imam Nawāwi menyatakan bahwa ia menyusun fatwanya berdasarkan urutan waktu pertanyaan muncul, ia menyatakan bahwa barangkali sutau ketika ada yang menyusunnya berdasarkan urutan kitab fiqh (Wael B. Hallaq, 1994: 37).

10. Fatwa pada masa Utsmani dan periode setelahya cenderung sangat praktis dan pragmatis (Wael B. Hallaq, 1994: 38).

\section{Perkembangan Fatwa dalam Lintasan Sejarah}

Ibnu Qayyim dalam kitabnya I'lām al-Mawāqi'in menyatakan bahwa institusi fatwa diperkenalkan oleh Nabi sendiri sejak Islam mulai berkembang ke daerah lain. Beliau bersedia menjawab pertanyaanpertanyaan yang diajukan kepadanya dan membuat keputusan hukum terhadapnya (Muhammad Jamāl al-Dīn al-Qāsimi, 1986: 31). Jawaban atas fatwa tersebut didasarkan pada kitab Allah, atau kadang-kadang didasarkan pada ijtihad Nabi sendiri sesuai bimbingan dan petunjuk dari Allah (Muhammad Jamāl al-Dīn al-Qāsimi, 1986: 31), bentuk yang kedua inilah yang kemudian disebut sebagai hadith (Saiyad Nizamudduin, 2006: 53).

Setelah Nabi Muhamamad Saw., wafat, tugas-tugas berfatwa tersebut dilanjutkan oleh para sahabatnya, fatwa tersebut kemudian dikenal dengan " fatwa șahaby". Pada masa ini materi fatwa dibagi kepada 2 (dua) bentuk, yaitu:

1. Fatwa yang materinya merupakan pengulangan kembali penjelasan-penjelasan dari al-Qur'ān dan Sunnah.

2. Fatwa yang materinya merupakan hasil ijtihad para sahabat. Bentuk inilah yang kemudian disebut sebagai " fatwa șahaby" (Muhlis, Kedudukan Fatwa Dalam Islam, http:/ / www.arsip.badilag.net/data/ARTIKEL/ fatwa \%20dalam\%20 islam.pdf di akses 28 Juli 2016). 
Setelah masa sahabat berakhir, kegiatan berfatwa dilanjutkan oleh tabi'in. Era tabi'in yang dimaksud dalam tulisan ini adalah masa peralihan kekuasaan pemerintahan ke tangan Bani Ummayah yang dipimpin oleh Mu'awiyah ibn Abī Sofyān sampai kurun waktu abad 2 (dua) hijriah berakhirnya kerajaan Bani Ummayyah (Al-Asyqar, 'Umar Sulaymān, 1982: 80). Generasi ini adalah mereka yang sempat berguru kepada tokoh-tokoh keilmuan dari generasi sahabat. Proses transformasi keilmuan yang berlaku antara sahabat dan tabi'in terjalin berdasarkan metode periwayatan (nuqil), baik secara langsung maupun tidak langsung. Secara langsung berarti tabi'in mendengar atau berguru secara langsung kepada seorang sahabat mengenai keputusan hukum dan fatwa yang dikemukakan sahabat Secara tidak langsung berarti tabi'in menghafal dan menguasai segala ketentuan hukum seorang sahabat walaupun tidak pernah mendengarnya sendiri dari sahabat tersebut. Sebagaimana Sa'îd Ibn al-Musayyah yang digelari sebagai perawi 'Umar lantaran penguasaannya terhadap seluruh ketetapan hukum dan fatwa yang pernah dikemukakan 'Umar sedang mereka tidak pernah bertemu (AlSyīrazī, 1978: 73).

Secara umum fatwa dan perundangan pada era tabi'in masih hampir sama dengan apa yang berlaku pada masa sahabat. Mereka masih berpegang pada kaedah ijtihad yang dilakukan oleh para sahabat yakni pertama merujuk pada al-Qur'ān kemudian Sunnah dan Ijtihad para sahabat, barulah kemudian ber-ijtihad sendiri apabila tidak ditemui jawaban dari sumber-sumber tersebut (Al-Asyqar, 'Umar Sulaymān, 1982: 81). Meskipun mereka mengikatkan diri dengan metodologi para sahabat, namun kadang-kadang mereka menggunakan al-ra'y dalam membuat keputusan hukum dan fatwa. Terlebih jika menghadapi perubahan dan fenoma baru dalam masyarakat.

Setelah masa tabi'in, fatwa berkembang melalui para imam-imam mujtahid dan pengikutnya. Pada masa ini masalah-masalah fiqh mulai dibukukan. Masalah-masalah yang dibukukan merupakan formulasi dari persoalan yang telah ditetapkan dalam al-Qur'ān dan hadith, fatwa sahabat dan fatwa-fatwa mujtahidin sebagai hasil ijtihad mereka pada waktu itu. Permasalahan-permasalah fīgh pada waktu itu disistematikakan dengan baik, sehingga memudahkan pembaca mencari masalah yang diinginkan.

Hal ini sebagaimana pernyataan Wael B.Hallaq sebagaimana dikutip oleh Rusli dalam artikelnya Tipologi Fatwa di Era Modern, sebagai berikut:

Ketika fatwa, yang memuat suatu hukum yang berbasis pada realitas sosial yang kongkret, dikeluarkan, kerapkali ia dimasukkan dalam 


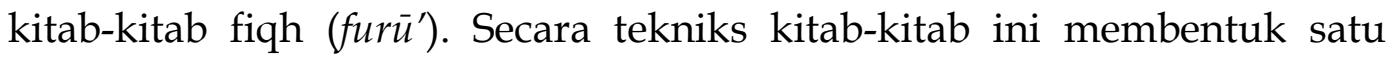
otoritas tertinggi sebagai kompilasi hukum. Meskipun memuat satu hierarki otoritas doktrinal, namun secara keseluruhan mereka mempresentasikan doktrin hukum standar dari mazhab-mazhab fiqh. Fatwa-fatwa yang telah dikeluarkan oleh mufti dimasukkan ke dalam karya-karya fiqh melalui dua saluran: langsung dan tidak langsung; contoh dari saluran lansung adalah fatwa-fatwa Ibn Ruṣd yang dimasukkan ke dalam karya-karya fiqh berjudul Mawāhib al-Jalīl dan Tahrīr al-Kalām yang keduanya disusun oleh al-Hatțāb, dan fatwa-fatwa dari ayahnya al-Ramlī yang dimasukkan oleh al-Ramlī ke dalam kitabnya yang merupakan komentar atau ulasan (syarh) terhadap kitab al-Minhāj karya al-Nawāwī (Rusli, Tipologi Fatwa di Era Modern, (Hunafa;Jurnal Studi Islamika, Vol 8, No.2, Desember 2011: 275).

Secara tidak langsung merupakan proses penyerapan fatwa ke dalam kitab fiqh melalui proses yang panjang seperti mengumpulkan, menyunting, dan mengikhtisar fatwa-fatwa primer untuk dimasukkan ke dalam koleksi-koleksi yang tidak terkait denagn fatwa dari para mufti tertentu, namun hanya mengumpulkan bahan-bahan fatwa untuk membentuk sebuah karya fikih. Hal tersebut oleh Wael B.Hallaq disebut sebagai modified fatwa ( fatwa yang telah dimodifikasi). Abū al-Lais alSamarqandī dan al-Nātifīi, misalnya, konon mengumpulkan dalam karyakarya mereka, Kitāb al-Nawāzìl dan Majmu'āt al-Nawazìl wa al-Wāqi'āt, fatwa-fatwa dari para imam mazhab dan juga fatwa-fatwa dari para mufti seperti Muhammad ibn Syuja' al-Ṭaljī, Muḥammad ibn Muqātil al-Rāzī dan Ja'far ibn 'Alī al-Hinduwānī (Rusli, 2011: 275).

Sebagaimana mengalami proses transformasi ketika diasimilasi ke dalam karya-karya fiqh, fatwa-fatwa primer juga mengalami transformasi yang sama dalam perjalanannya dari primary fatwa kepada modified fatwa. Untuk sampai kepada modified fatwa ini, proses tersebut melibatkan dua cara: tajrid dan tahklis. Tajrid adalah suatu proses penghilanagan rincianrincian seperti penalaran yang mengantarkan kepada pendapat yang diekspresikan dalam fatwa, nama-nama nyata atau hipotesis yang kebetulan disebutkan. Ia juga mencangkup penghilangan semua kata dan frase yang tidak relevan dengan hukum, seperti formula-formula keagamaan, dan frase-frase " Dia ditanya..." dan " Dia menjawab..." dan kalimat-kalimat pengantar yang mengindikasikan bahwa para mufti telah membaca dengan seksama dan mempelajari fatwa tersebut. Dan karena sebagian fatwa memuat dokumen-dokumen hukum, khususnya yang terkait dengan kontrak, maka fungsi tajrid-lah yang menghilangkan dokumen-dokumen ini juga. Namun, karena penghilangan total terhadap dokumen mungkin dapat mendistorsi fakta-fakta dann hukum dalam 
sebuah fatwa (surah al-fatwā), maka praktik yag kedua adala melalui proses talkhiṣ (ikhtisar) (Rusli, 2011: 275).

Perkembangan fatwa selanjutnya adalah pada era modern ditandai dengan munculnya para ulama kontemporer seperti Yusuf al-Qardawi dan Wahbah Zuhaili. Qarḍawi,misalnya, dalam mengeluarkan fatwa bertumpu pada hal-hal berikut; a) tidak fanatik atau taqlid, namun demikian ia tetap menghormati kepada para imam mazhab dengan cara menggunakan motode dan cara pandang mereka, tidak mengemukakan pendapat tanda dalil yang kuat, mampu men-tarjih yang paling kuat, b). mempermudah tidak mempersulit, c) berbicara dengan bahasa yang mudah dimengerti, d) berpaling dari sesuatu yang tidak bermanfaat, e) bersikap pertengahan tidak memperlonggar dan memperketat, f) memberikan hak fatwa yang berupa keterangan dan penjelasan. Kemudian Wahbah Zuhaili, dalam fatwanya memiliki karakteristik sebagai berikut; a) terlebih dahulu melakukan kajian terhadap naș, b) Apabila tidak menemukan hadith dari masalah yang sedang dikajinya ia menggunakan hadith 'amaliyah atau taqririyah sebagai dalil, c) jika dari kedua sumber tersebut tidak ditemukan, Wahbah Zuhaili memperhatikan pendapat-pendapat ulama dengan memperhatikan keabsahan hadith yang dijadikan dalil para ulama tersebut, d) melakukan tarjīh terhadap pendapat yang mengacu pada sandaran yang șahīh (Faridatus Suhadak, Urgensi Fatwa dalam Pekembangan Hukum Islam, (de Jure, Jurnal Syariah dan Hukum, Vol 5 No 2, Desember 2013) h. 189-196).

Selain munculnya mufti-mufti kontemporer dengan metodologi masing-masing, muncul juga apa yang disebut sebagai mufti Negara. Mufti Negara adalah "pejabat Negara, birokrat, dan tokoh penting dalam administrasi keagamaan". Mereka lebih cenderung meliat dirinya sebagai instrument Negara, pembela syariah dan norma-norma keislaman dalam sebuah masyarakat. Mereka justru mengklaim menggunakan Negara sebagai instrument untuk memunculkan kebijakan-kebijakan keagamaan, sebuah klaim yang mengandung kebenaran, dalam arti bahwa mufti Negara mempunyai anggaran dan kewenangan untuk menyelenggarakan berbagai konferensi, menerbitkan Lembaga Fatwa, membuat berbagai kebijakan, untuk mempengaruhi publik tentang isu-isu yang dirasa mengancam norma-norma, nilai-nilai, dan aturan-aturan keagamaan (Rusli, 2011: 279-283). Peran mufti Negara ini berbeda dari satu Negara dengan Negara lainnya. Sebagian merupakan mufti yang berada dalam kontrol yang ketat dan aktif dari Negara seperti di Saudi Arabia, para mufti yang terkumpul dalam al-Lajnah al-Da'imah li al-Buḥūs wa al-Iftá' diangkat oleh Negara. Namun para mufti ini berada dalam kontrol dan pengaruh yang sangat kuat dari Negara (kerajaan). Segala fatwa yang dikeluarkan tidak akan keluar dari mazhab resmi Negara dan juga dari 
kebijakan dan stabilitas politik kerajaan. Figur penting yang mewarnai lembaga ini adalah 'Abd al-'Azīz Ibn Bāz, yang keterikatannya pada mazhab Hanbali dan ajaran-ajaran Muhammad ibn 'Abd al-Wahhāb sangat kuat, dan perannya dalam melegitimasi berbagai kebijakan kerajaan tidak diragukan lagi (Rusli, 2011: 279-283).

Sedangkan sebagian yang lain merupakan mufti Negara yang dapat mengambil inisiatif sendiri. Sebagai contoh adalah jabatan mufti Negara Dār al-Iftă' di Mesir, yang dibentuk pada tahun 1895 dan diperluas sehingga menjadi satu lembaga yang besar. Tugasnya adalah merespon setiap pertanyaan yang diajukan oleh setiap individu, lembaga-lembaga publik, dan juga Negara. Menurut Skovgaard Petersen dari abad ke-19, mufti menjadi pelayan publik yang diangkat langsung oleh kepala Negara, dan mendapat julukan Muftì al-Diyār al-Mișriyah (Mufti wilayah Mesir), kemudian diganti dengan Muftī al-Jumhūrìyah (Mufti Republik). Seluruh hierarki mufti dibentuk, dan ditempatkan diberbagai pengadilan dan departemen pemerintahan, sehingga kodifikasi dan rasionalisasi proses hukum membuat jumlah mereka menjadi terlalu berlebihan. Fungsi ift $\bar{a}^{\prime}$ semakin diketahui publik, yang dipermudah dengan peran peretakan dan massa. Fatwa-fatwa yang dikeluarkan tersebut disimpan dan diklasifikasikan secara sistematis, kemudian dicetak dalam berbagai koleksi. Media massa memperluas penyebaran fatwa tentang isu-isu sosial dan politik yang diorientasikan kepada publik ini (Rusli, 2011: 279-283).

Dalam kondisi lain, mufti Negara merupakan seorang yang agak marjinal, kurang tertarik pada Negara atau publik secara umum. Seperti di Syiria, Negara melakukan upaya besar untuk mengontrol pengangkatan dan aktifitas mufti Negara. Mufti negara di Syiria, misalnya Muhammad Abū al-Yusr 'Ābidīn (1890-1981), yang dipilih pada tahun 1954, dimarjinalkan dan bahkan dipecat oleh negara. Hal ini karena resistansi dan oposisinya yang keras terhadap negara karena tindakan negara yang semena-mena mengambil alih dan menyita hak-hak kepemilikan pribadi. Di Syiria, tampak jelas bahwa kekuatan negara vis a vis mufti negara begitu besar, sehingga ruang kemandirian mufti tidak dibuka lebar. Negara dengan mudah mencopot posisi mufti negara jika mufti tersebut dianggap dapat membahayakan kekuasaannya. Begitu pula, marjinalisasi mufti terbukti dengan intensitasnya keterlibatan mufti dalam tugas-tugas pendidikan dan pengajaran, dana tidak dibebani dengan iftä' (Rusli, 2011: 279-283).

\section{Perubahan Karakter Fatwa Ekonomi Syariah DSN-MUI}

Sebagaimana telah disinggung sebelumnya bahwa sampai dewasa ini DSN-MUI telah menetapkan 125 fatwa dibidang ekonomi syariah. Dari 125 fatwa tersebut setidaknya terdapat lebih dari 59 fatwa yang tidak 
disebutkan identitas pihak pemohon fatwa. Secara umum fatwa-fatwa yang dikeluarkan DSN-MUI terdapat dalam Angka 3 Bab IV tentang Prosedur Rapat dalam Pedoman dan Prosedur Penetapan Fatwa MUI Tahun 2001. Hal itu didasarkan pada:

a. Permintaan atau pertanyaan dari masyarakat yang oleh Dewan Pimpinan dianggap perlu dibahas dan diberikan fatwanya.

b. Permintaan atau pertanyaan dari pemerintah, lembaga/organisasi sosial, atau MUI sendiri.

c. Perkembangan dan temuan masalah-masalah keagamaan yang muncul akibat perubahan masyarakat dan kemajuanilmu pengetahuan dan teknologi.

Apa yang disinggung dalam pedoman tersebut mengindikasikan bahwa DSN-MUI tidak hanya bersifat responsif menunggu adanya pemohon fatwa di bidang ekonomi syariah. Akan tetapi, ia dapat pula bersifat proaktif menanggapi masalah-masalah keagamaan yang muncul di masyarakat. Dalam kaitan pemohon fatwa ekonomi syariah DSN-MUI, ada yang disebutkan secara langsung ${ }^{1}$ dan ada yang tidak disebutkan siapa pemohon fatwa dalam keputusan fatwa DSN-MUI, meskipun begitu secara umum DSN-MUI tetap menyebutkan kepada siapa fatwa tersebut ditujukan. Sasaran atau subyek fatwa DSN-MUI umumnya selalu disebutkan pada bagian pertimbangan fatwa yang merupakan bagian dari format fatwa DSN-MUI, sebagai contoh fatwa tentang kafalah dalam bagaian pertimbangan huruf c disebutkan bahwa bahwa "agar kegiatan kafalah tersebut dilakukan sesuai dengan ajaran Islam, DSN memandang perlu menetapkan fatwa tentang kafalah untuk dijadikan pedoman oleh LKS".

Selain itu, berdasarkan Keputusan Dewan Syariah Nasional No: 01 Tahun 2000 Tentang Pedoman Dasar Dewan Majelis Ulama Indonesia (PD DSN-MUI) atas pedoman dasar dan Pedoman Rumah Tangga Majelis Ulama Indonesia periode 1995-2000, dan Surat Keputusan Dewan Pimpinan Majelis Ulama Indonesia No: Kep-754/MUI/II/99 tentang pembentukan Dewan Syariah Nasional huruf d dinyatakan sebagai berikut:

Dewan Syariah Nasional berperan secara pro-aktif dalam menanggapi perkembangan masyarakat Indonesia yang dinamis dalam bidang ekonomi dan keuangan. Perilaku proaktif merupakan upaya mengambil inisiatif dalam meningkatkan ide

\footnotetext{
${ }^{1}$ Misalnya fatwa tentang Pedoman Pelaksanaan Investasi Untuk Reksadana Syariah dalam format fatwa bagian "memperhatikan" huruf c disebutkan bahwa penetapan fatwa memperhatikan surat dari PT. Danareksa Investment Management, Nomor S-09/01/PS-DIM.
} 
dan kreativitas-kreativitas baru mengubah status quo dibanding hanya bertindak pasif dalam menghadapi kondisi saat ini. (Yuni Siswanti, Pengaruh Kepribadian Proaktif Terhadap Kesuksesan Karier Dengan Political Influence Behavior Sebagai Variabel Pemediasi, PROSIDING dalam rangkaian SEMINAR INTERNASIONAL DAN CALL FOR PAPERS “TOWARDS EXCELLENT SMALL BUSINESS" Yogyakarta, 27 April 2011, h. 77).

Sikap pro-aktif terhadap permasalahan yang terjadi tersebut bila dikaitkan dengan konsep ift $\bar{a}^{\prime}$ yang pada dasarnya lebih bersifat pasif menunjukkan bahwa konsep ift $\bar{a}^{\prime}$ DSN-MUI telah mengalami perkembangan dibandingkan konsep ifta 's sebelumnya.

Berdasarkan hal tersebut terlihat bahwa sebenarnya proses ift $\bar{a}^{\mathrm{e}}$ DSN-MUI tidak hanya diarahkan pada upaya menjawab status hukum dari permasalahan yang ditanyakan, akan tetapi lebih mengarah kepada bagaimana memodifikasi transaksi-transaksi yang terjadi agar sesuai dengan prinsip syariah. Perubahan Karakteristik fatwa juga telah terlihat dalam Pedoman dan Penyelenggaraan Organisasi Majelis Ulama Indonesia (MUI) dimana MUI berperan sebagai mufti (Pemberi fatwa). Peran ini menempatkan MUI untuk memberikan fatwa terutama persoalan berkaitan dengan hukum Islam, baik diminta maupun tidak diminta. Sebagai lembaga pemberi fatwa MUI nengakomodir dan menyalurkan aspirasi umat Islam Indonesia yang sangat beragam aliran dan paham dan pemikiran serta organisasi keagamaannya (Hasil Rakernas Tahun 2011, Pedoman Penyelenggara Organisasi Majelis Ulama Indonesia (Jakarta: Sekretariat Majelis Ulama Indonesia Pusat, 2011) h. 10 13).

Selanjutnya, selain berkaitan dengan sifat fatwa yang lebih proaktif perubahan yang terjadi pada fatwa ekonomi syariah DSN-MUI adalah berkaitan dengan format putusan fatwa yang dikeluarkan. Sebagaimana dijelaskan di atas bahwa dalam format tradisionalnya fatwa terdiri atas tiga unsur pertanyaan (su'äl,istifta'), pemberi fatwa (mufti), dan jawaban (jawāb) yang kemudian disebut $r u q^{\prime}$ ah al-istift $\bar{a}^{\prime}$. Sebagai contoh dari format fatwa tradisional adalah sebagai berikut:

Pertanyaan : seseorang menitipkan kuda di pasar dan kemudian orang yang dititipi menungganginya di jalan dengan maksud untuk menjaganya, kemudian ia jatuh.

Jawab : Jika tidak ada cara lain untuk menjaga kuda tersebut kecuali dengan menungganginya dan tidak berlebihan dalam menungganinya dan kemudian terjatuh dengan tanpa sengaja, maka tidak berakibat apa-apa ('Ali Aḥmad Khațīb, Fatāwā al-Imām al-Nawawy, t.th: 86). 
Format fatwa klasik tersebut jika kemudian dibandingkan dengan format putusan fatwa DSN-MUI, jelas sangat berbeda. Ciri utama dari fatwa DSN-MUI adalah sistematika penyusunan fatwa yang lebih formal yang dituangkan dalam Surat Keputusan Fatwa (SKF). Di dalam SKF, harus dicantumkan dasar-dasar pengambilan hukum disertai uraian dan analisis secara ringkas, serta sumber pengambilannya. Demikian pula setiap SKF sedapat mungkin disertai dengan rumusan tindak lanjut dan rekomendasi dan / atau jalan keluar yang diperlukan sebagai konsekuensi dari SKF tersebut. Untuk lebih jelasnya, format fatwa DSNMUI dapat dilihat dalam Ijtima Ulama Komisi Fatwa se-Indonesia tanggal 20-22 Syawal 1424 H/ 14-16 Desember 2003 M tentang Pedoman Penetapan Fatwa Majelis Ulama Indonesia bab V, sebagai berikut :

a. Fatwa dirumuskan dengan bahasa hukum yang mudah dipahami oleh masyarakat luas;

b. Fatwa memuat :

1) Nomor dan judul fatwa;

Contoh penulisan nomor dan judul dalam fatwa DSN-MUI seperti,

"FATWA DEWAN SYARI'AH NASIONAL NO: 01/DSNMUI/IV/2000 Tentang GIRO"

2) Kalimat pembuka basmallah;

3) Konsideran yang tediri atas:

a) Menimbang, memuat latarbelakang, alasan, dan urgensi penetapan fatwa.

Contohnya sebagai berikut:

Menimbang:

a. bahwa keperluan masyarakat dalam peningkatan kesejahteraan dan dalam bidang investasi, pada masa kini, memerlukan jasa perbankan; dan salah satu produk perbankan di bidang penghimpunan dana dari masyarakat adalah giro, yaitu simpananm dana yang penarikannya dapat dilakukan setiap saat dengan penggunaan cek, bilyet giro, sarana perintah pembayaran lainnya, atau dengan pemindahbukuan;

b. bahwa kegiatan giro tidak semuanya dapat dibenarkan oleh hukum Islam (syari'ah); 
c. bahwa oleh karena itu, Dewan Syari'ah Nasional (DSN) memandang perlu menetapkan fatwa tentang bentuk-bentukm mu'amalah syar'iyah untuk dijadikan pedoman dalam pelaksanaan giro pada bank syari'ah (Pertimbangan dari FatwaDewan Syari'ah NasionalNo: 01/DSNMUI/IV/2000TentangGIRO).

b) Mengingat, memuat dasar-dasar hukum (adillah al-aḥkām)

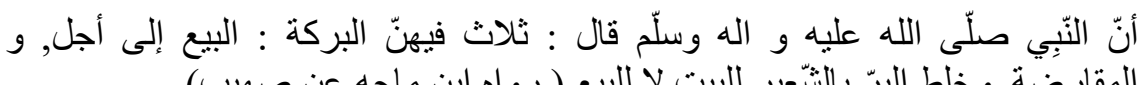

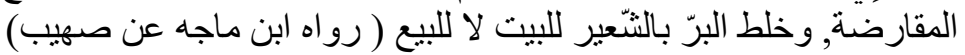

“Nabi bersabda, ada tiga hal yang mengandung berkah: jual beli tidak secara tunai, muqāraḍah, dan mencampur gandum dengan jejawut untuk keperluan rumah tangga, bukan untuk di jual (HR. Ibnu Mājah dari Șuhayb) (Fatwa Dewan Syari'ah Nasional No: 01/DSN-MUI/IV/2000 Tentang GIRO).

c) Memperhatikan, memuat pendapat peserta rapat, para ulama, pendapat ahli, dan hal-hal lain yang mendukung penetapan fatwa.

Contoh, "Pendapat peserta Rapat Pleno Dewan Syari'ah Nasional pada hari Sabtu, tanggal 26 Dzulhijjah 1420 H./1 April 2000."

4) Diktum, memuat:

a) subtansi hukum yang difatwakan, dan

Menetapkan : FATWA TENTANG GIRO

Pertama : Giro ada dua jenis:

1. Giro yang tidak dibenarkan secara syari'ah, yaitu giro yang berdasarkan perhitungan bunga.

2. Giro yang dibenarkan secara syari'ah, yaitu giro yang berdasarkan prinsip Mudharabahdan Wadi'ah.

Dst (Fatwa Dewan Syari'ah Nasional No: 01/DSN-MUI/IV/2000 Tentang GIRO).

b) rekomendasi dan/atau jalan keluar, jika dipandang perlu.

Contoh, "Jika salah satu pihak tidak menunaikan kewajibannya atau jika terjadi perselisihan di antara kedua 
belah pihak, maka penyelesaiannya dilakukan melalui Badan Arbitrasi Syari'ah setelah tidak tercapai kesepakatan melalui musyawarah (Fatwa Dewan Syariah Nasional Majelis Ulama Indonesia No: 100/DSN-MUI/IXII/2015 Tentang: Pedoman Transaksi Voucher Multi Manfaat Syariah)."

5) Penjelasan, berisi uraian secukupnya tentang fatwa

Contoh :

Ketiga Ketentuan Transaksi

1. Syarat Penjual/Penerbit Voucher:

a. Telah memiliki atau mempunyai kewenangan untuk menjual obyek akad (manfaat voucher/mabi');

b. Telah memiliki kemampuan dan sarana pendukung teknis (termasuk pusat pengolahan data) untuk merealisasikan pelaksaanaan manfaat voucher (Fatwa Dewan Syariah Nasional Majelis Ulama Indonesia No: 100/DSNMUI/IXII/2015 Tentang :Pedoman Transaksi Voucher Multi Manfaat Syariah);

6) Lampiran-lampiran, jika dipandang perlu.

c. Fatwa ditandatangi oleh ketua sekretaris komisi (Keputusan Ijtima' Ulama Komisi Fatwa Se-Indonesia Pertama Tahun 2003).

Format fatwa sebagaimana diuraikan di atas ternyata memiliki kemiripan dengan ketentuan perumusan ketentuan perundang-undangan dalam hukum formal yang secara umum harus memuat hal-hal sebagai berikut:

a. Judul

b. Pembukaan

Dalam pembukaan ini harus dimuat beberapa hal, yakni; 1) Frase dengan Rahmat Tuhan Yang Maha Esa, 2). Jabatan Pembentuk Undang-Undang, 3) Konsideran, 4) Dasar Hukum, 5) Diktum (kata memutuskan, menetapkan).

c. Batang Tubuh

Pada bagian batang tubuh ini terdiri atas unsur-unsur sebagai berikut; Ketentuan Umum, Materi yang diatur, Ketentuan Pidana (jika diperlukan), Ketentuan Peralihan (jika diperlukan), Ketentuan Penutup.

d. Penutup 


\section{e. Penjelasan}

f. Lampiran (Astim Riyanto, 2009: 25).

Berdasar paparan di atas terlihat bahwa fatwa DSN-MUI telah mengalami perubahan yang signifikan dari format fatwa tradisional yang hanya berisi uraian, pertanyaan dan jawaban saja. Perubahan format tersebut tidak lepas dari persoalan otoritas fatwa DSN-MUI yang berasal dari amanat undang-undang sebagaimana dijelaskan di atas dan kedudukan dari DSN-MUI sendiri yang merupakan lembaga semipemerintah. Adapun titik temu antara format fatwa dengan undangundang atau pemerintah dibuktikan dengan kemiripan format fatwa DSN-MUI dengan format perumusan peraturan perundang-undangan sebagaimana di uraikan dalam Undang-Undang Nomor 12 Tahun 2011 tentang Pembentukan Peraturan Perundang-undangan Pasal 64. ${ }^{2}$ Oleh karena itu, dari sisi format fatwa DSN-MUI cenderung mengadopsi konsep perumusan peraturan perundang-undangan dibandingkan dengan konsep perumusan fatwa dalam ruq'ah al-fatwa.

\section{Kesimpulan}

Berdasarkan analisis di atas penulis menyimpulkan beberapa hal sebagai berikut, pertama, Fatwa DSN-MUI tidak hanya sebagai jawaban atas pertanyaan yang memiliki kaitan dengan hukum agama tetapi juga merupakan respon aktif dari DSN-MUI dalam menanggapi permasalahan ekonomi Syariah.Kedua, Pada umumnya mufti berhak memberikan fatwa tentang persoalan kehidupan meliputi aqīdah, 'ibadah, akhlāq, dan mu'amālah. Akan tetapi, DSN-MUI hanya berwenang memberikan fatwa khusus dalam bidang ekonomi syariah saja. Perubahan berikutnya yang terjadi pada DSN-MUI adalah pada aspek format fatwa (ruq'ah al-fatwa). Fatwa-fatwa terdahulu umumnya hanya memuat unsur pertanyaan, mufti, jawaban dan dasar hukum. Akan tetapi, dalam fatwa DSN-MUI ini sebagaimana dipaparkan sebelumnya penyusunannya hampir mirip dengan peraturan perundang-undangan. Format fatwa DSN-MUI tersebut dapat dilihat dalam Keputusan Ijtima' Ulama Komisi Fatwa Se-Indonesia tahun 2003 BAB V tentang Format Fatwa.

\footnotetext{
${ }^{2}$ Ayat (1) Penyusunan Rancangan Peraturan Perundang-undangan dilakukan sesuai dengan teknikpenyusunanPeraturan Perundang-undangan. Ayat (2) Ketentuan mengenai teknikpenyusunan Peraturan Perundang-undangan sebagaimana dimaksud padaayat (1) tercantum dalam Lampiran II yang merupakan bagian tidak terpisahkan dari Undang-Undang ini.(3)Ketentuan mengenai perubahan terhadap teknik penyusunan Peraturan Perundangundangansebagaimana dimaksud pada ayat (2) diatur dengan Peraturan Presiden
} 


\section{DAFTAR PUSTAKA}

....., Mațalib Ūly al-Nuhā fi Syarh Ghayah al-Munțaha, (Beirut: Dār al-Fikr).

Al-Asyqar, 'Umar Sulaymān, Tärikh al-Fiqh al-Islāmī, (Kuwait: Maktabah Al-Falāh, 1982).

Al-Syīrazī, Ṭabaqāt al-Fuqahā', Juz 6, (Beirut: Dār al-Rā'id Al-'Arabī, 1978).

al-Qāsimi, Muhammad Jamāl al-Dīn, al-Fatwā fi al-Islām, (Beirut: Dar alKutub al-'ilmiyah, 1986).

Dahlan, Abdul Aziz, et.al., Ensiklopedi Hukum Islam, (Jakarta : Ichtiar Baru van Hoeve, 1996).

Depdikbud, Kamus Besar Bahasa Indonesia, (Jakarta : Balai Pustaka, 1997).

Fatah, Rohadi Abdul, Analisis Fatwa Keagamaan dalam Fiqih Islam, ( Jakarta : PT. Bumi Aksara, 2006).

Hallaq, Wael B., From Fatwās to Furu' :Growth and Change in Islamic Subtantive Law, (Islamic Law and Society. Vol.1. No.1 (1994), h. 2965.

Haroen, Nasroen, Ūșul Fiqh1, (Jakarta : Logos Wacana Ilmu, 2001), cet.3.

Hasil Rakernas Tahun 2011, Pedoman Penyelenggara Organisasi Majelis UlamaIndonesia (Jakarta : Sekretariat Majelis Ulama Indonesia Pusat, 2011).

Khațīb, ‘Ali Ahmad, Fatāwā al-Imām al-Nawawy, t.th.

Lihat https://dsnmui.or.id/kategori/fatwa/ di akses 05 Agustus 2019.

Maslihan, Mohammad Ali, Sejarah Revitalisasi Pemikiran Hukum dalam Metodologi Fatwa, dalam A. Dimyati, dkk, Rekontruksi Metodologi Fatwa Perbankan Syariah, (Pati : CSIF, 2015).

Muhlis, Kedudukan Fatwa Dalam Islam, http://www.arsip.badilag.net/data/ARTIKEL/fatwa\%20dalam\% 20islam.pdf di akses 28 Juli 2016.

Nizamudduin, Saiyad, Fatwa of Condemnation: Islam and the Limit of Dissent (Kuala Lumpur: ISTAC-IIUM, 2006).

Qardiawi, Yusuf, Fiqh Prioritas, (Mansyurat Kuliah Da'wah Islamiyah, 1990).

Riyanto, Astim, Teknik Perancangan Peraturan Perundang-Undangan, makalah disajikan dalam Pelatihan Kesekertariatan Universitas Indonesia, (Universitas Pendidikan Indonesia :Panitia Pelatihan Kesekertariatan, 2009).

Rusli, Tipologi Fatwa di Era Modern, (Hunafa;Jurnal Studi Islamika, Vol 8, No.2 , Desember 2011:269-306).

Schacht, Joseph, An Introduction to Islamic Law, (London : Oxford University Press, 1965).

Suhadak, Faridatus, Urgensi Fatwa dalam Pekembangan Hukum Islam, (de Jure, Jurnal Syariah dan Hukum, Vol 5 No 2, Desember 2013).

Zuhaily, Waḥbah, Ușul Fiqh, t.tp, (Mansyurat Kuliah Da'wah Islamiyah, 1990). 